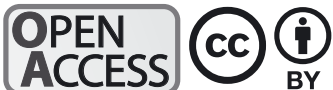

\section{Chilled frogs are hot: hibernation and reproduction of the Endangered mountain yellow-legged frog Rana muscosa}

\author{
Frank E. Santana ${ }^{1,2}$, Ronald R. Swaisgood ${ }^{1, *}$, Jeffrey M. Lemm ${ }^{1}$, Robert N. Fisher ${ }^{3}$, \\ Rulon W. Clark ${ }^{2}$
}

\begin{abstract}
${ }^{1}$ San Diego Zoo Institute for Conservation Research, 15600 San Pasqual Valley Road, Escondido, CA 92027, USA
${ }^{2}$ Department of Biology, San Diego State University, 5500 Campanile Drive, San Diego, CA 92182, USA

${ }^{3}$ US Geological Survey, San Diego Field Station, 4165 Spruance Road, Suite 200, San Diego, CA 92101, USA
\end{abstract}

\begin{abstract}
In the face of the sixth great extinction crisis, it is imperative to establish effective breeding protocols for amphibian conservation breeding programs. Captive efforts should not proceed by trial and error, nor should they jump prematurely to assisted reproduction techniques, which can be invasive, difficult, costly, and, at times, counterproductive. Instead, conservation practitioners should first look to nature for guidance, and replicate key conditions found in nature in the captive environment, according to the ecological and behavioral requirements of the species. We tested the effect of a natural hibernation regime on reproductive behaviors and body condition in the Endangered mountain yellow-legged frog Rana muscosa. Hibernation had a clear positive effect on reproductive behavior, manifesting in vocal advertisement signaling, female receptivity, amplexus, and oviposition. These behaviors are critical components of courtship that lead to successful reproduction. Our main finding was that captive $R$. muscosa require a hibernation period for successful reproduction, as only hibernated females produced eggs and only hibernated males successfully fertilized eggs. Although hibernation also resulted in a reduced body condition, the reduction appeared to be minimal with no associated mortality. The importance of hibernation for reproduction is not surprising, since it is a major component of the conditions that $R$. muscosa experiences in the wild. Other amphibian conservation breeding programs can also benefit from a scientific approach that tests the effect of natural ecological conditions on reproduction. This will ensure that captive colonies maximize their role in providing genetic reservoirs for assurance and reintroduction efforts.
\end{abstract}

KEY WORDS: Hibernation - Amphibian · Assurance colony $\cdot$ Captive breeding $\cdot$ Reproductive behavior

\section{INTRODUCTION}

Amphibians throughout the world are in decline, with $41 \%$ of the world's 6638 known amphibian species threatened with extinction (Hoffmann et al. 2010). Conservation breeding in captivity is an important tool used to protect endangered amphibians from the immediate threat of extinction and pro-

${ }^{*}$ Corresponding author: rswaisgood@sandiegozoo.org vide offspring for long-term recovery efforts (Griffiths \& Pavajeau 2008). Several amphibian species survive only in captive colonies (Gratwicke et al. 2012), and the International Union for Conservation of Nature has called for the establishment of captive assurance colonies for Endangered amphibians (Gascon et al. 2007). Developing a successful conservation breeding program for endangered amphibians

() San Diego Zoo Global and R. W. Clark 2015. Open Access under Creative Commons by Attribution Licence. Use, distribution and reproduction are unrestricted. Authors and original publication must be credited. 
is often difficult because establishment of ex situ programs is delayed until in situ populations are approaching extinction, and breeding efforts are compromised by a dearth of knowledge about reproductive biology (Zippel et al. 2011).

Captive management that looks to nature and species' ecological requirements for guidance can reduce time wasted on trial-and-error learning and can expedite establishment of successful reproduction (Hosey et al. 2009). While assisted reproduction techniques such as hormone injections are sometimes necessary, their use is in effect an admission that our understanding of behavioral and ecological requirements is lacking. Moreover, invasive attempts at artificial reproduction can sometimes run counter to conservation breeding goals because handling of sensitive species can negatively impact health and survival (Waggener \& Carroll 1998, Byrne \& Silla 2010, Roth et al. 2010). Animal welfare and conservation goals sometimes conflict (Wall 2010), but in conservation breeding and reintroduction programs, efforts to enhance individual animal welfare can also enhance conservation outcomes (Swaisgood 2007, 2010).

The mountain yellow-legged frog Rana muscosa is an Endangered ranid with a disjunct distribution in the southern Sierra Nevada Mountains and the Transverse and Peninsular Ranges in southern California, USA. The southern California population of $R$. muscosa, which is protected as an endangered distinct population segment under the US Endangered Species Act of 1973 and the California Endangered Species Act, has declined across $99 \%$ of its historic range (Vredenburg et al. 2007). The population bottleneck experienced by the southern population may be contributing to loss of genetic diversity, indicating the immediate risk of inbreeding depression as an additional threat (Schoville et al. 2011).

The goal of the present study was to use $R$. muscosa as a model in establishing a captive management paradigm that supports reproduction for the rapid growth of captive amphibian populations. The captive $R$. muscosa population at the San Diego Zoo Institute for Conservation Research (ICR) serves as an assurance population against extinction in wild populations which are small and extremely vulnerable. Captive reproduction is also important to arrest the loss of genetic diversity in the captive-wild metapopulation (Schoville et al. 2011). In addition to the assurance function, this captive population is part of an active reintroduction program, supplying individuals to re-establish populations in suitable but unoccupied habitat.
One important component of many temperate amphibian species' life histories is a prolonged period of inactivity during cold weather associated with overwintering, which we refer to as hibernation (see review by Browne \& Zippel 2007). Hibernation can positively impact growth rates, maturation size, and survival (Reading 2007), and it can regulate reproductive hormone levels in amphibian species (Kim et al. 1998). While hibernation for captive breeding is widely practiced in the zoo and aquarium trade, surprisingly few scientific papers have addressed this topic. To our knowledge, only a single study has tested the effect of hibernation on amphibian reproduction. Although that study found that hibernated western toads Anaxyrus boreas treated with hormones had increased rates of amplexus compared to non-hibernated animals (Roth et al. 2010), it is difficult to disentangle the effects of hibernation from the effects of exogenous hormones.

Hibernation plays an important role in the natural history of $R$. muscosa. In the Sierra Nevada, $R$. muscosa hibernates underwater in lakes and streams for periods of 6 to 9 mo prior to the spring breeding season (Bradford 1984). Although hibernation has never been directly observed in southern California populations of $R$. muscosa, field observations indicate that they may hibernate for up to 6 mo underwater, utilizing deep stream pools (A. Backlin pers. comm.). Here we tested the hypothesis that over-winter hibernation mimicking the thermal regime experienced by $R$. muscosa in nature will have positive consequences for captive reproduction. We measured the effects of hibernation on multiple reproductive behaviors, including the response of frogs to male advertisement calls and the occurrence of courtship behaviors when frogs are paired for breeding. In addition, we used a body condition index as a measure of the effect of hibernation on frog health.

We focused on male advertisement calls in part because acoustic communication plays a critical role in mediating reproduction in most anuran species (Bee 2007, Arch \& Narins 2009), and seasonal variation in receptiveness to acoustic cues has been demonstrated in many temperate anuran species (Bosch et al. 2003, Goense \& Feng 2005, Wilczynski \& Lynch 2011). Male frogs use advertisement calls to inform gravid females of their location and reproductive condition (Schwartz et al. 2004). Males are also known to eavesdrop on calls of other males to locate areas of breeding activity (Bee 2007). Female frogs have been shown to respond with an increased attraction to advertisement calls as they approach ovulation (Miranda \& Wilczynski 2009) and in correlation with steroid hormone 
peaks associated with the breeding season (Lynch et al. 2006, Lynch \& Wilczynski 2005). The directed movement towards advertisement calls is known as phonotaxis (Wells 1977) and is a critical step for a successful breeding encounter. Advertisement call playbacks were used to test how hibernation affects phonotaxic response in $R$. muscosa.

After male and female anurans physically locate each other, they often engage in complex courtship behaviors involving multiple cues that allow them to communicate reproductive receptiveness (Preininger et al. 2013, Reichert 2013, Lima et al. 2014). We measured 6 courtship behaviors in breeding pairs of $R$. muscosa to determine the effect of hibernation on reproduction. Examining a suite of reproductive behaviors critical in driving reproductive success or failure allows for the measurement of subtle behaviors that can be used to gauge reproductive interest even when an encounter does not result in egg fertilization. To our knowledge, this is the first study to experimentally quantify the effect of a hibernation regime, without the use of hormone injections, on an amphibian conservation breeding program.

\section{MATERIALS AND METHODS}

\section{Hibernation protocol}

A total of 48 wild caught frogs collected from the San Jacinto Mountains in Riverside County, California, were housed as a captive assurance colony at ICR. These 48 individuals were separated into 2 treatment groups, an experimental hibernated group and a non-hibernated control group. Treatment groups were balanced by size and sex by ranking males and females separately by weight and assigning them in alternating order to the hibernated or non-hibernated group.

The 24 hibernated frogs (16 females and 8 males) were housed at $4^{\circ} \mathrm{C}$ for a period of $60 \mathrm{~d}$. This temperature was chosen because previous experiments on Rana muscosa (Bradford 1983) demonstrated it as safe and sufficient to induce physiological changes associated with hibernation. This temperature also approximated the average winter temperature of $2.5^{\circ} \mathrm{C}$ that was measured over a $3 \mathrm{yr}$ period at a frogoccupied pool in southern California (A. Backlin unpublished data).

Two weeks prior to hibernation, frogs were fasted to prevent undigested food from remaining in the gut. Three to 4 frogs of the same sex were housed in 14 l plastic containers filled halfway with water. The container was furnished with a platform placed above the water level to serve as a dry refuge. Each container was placed in refrigerated incubators, and the temperature was lowered incrementally over a 2 wk period from 13 to $4^{\circ} \mathrm{C}$. During hibernation, frogs were held without a photoperiod. Water in each container was changed twice a week to maintain water quality.

A group of 24 control frogs (16 females and 8 males) were not hibernated. These frogs were housed separately by sex in $\sim 3781$ (100 gallon) tanks with flowing water maintained at $13^{\circ} \mathrm{C}$ and an $8 \mathrm{~h}$ photoperiod and fed as usual.

\section{Body condition}

A body condition index (BCI) can provide information about the effects of hibernation on energy consumption and frog health. We used a BCI value of weight divided by total length (Karraker \& Welsh 2006), where lower BCI values corresponded to a reduced body condition. BCI was recorded twice for both the experimental and the control group, once before any frogs were hibernated (Time 1) and again after the $60 \mathrm{~d}$ hibernation period (Time 2).

\section{Phonotaxis}

A male advertisement call was recorded from a single adult at the ICR using a Sennheiser Electronic Corporation model ME 66 microphone and Tascam corporation model HD-P2 digital recorder set at a high-resolution sampling rate of $44.1 \mathrm{kHz} \mathrm{s}^{-1}$. The advertisement recording was obtained $30 \mathrm{~cm}$ from a partially submerged calling male frog while it had its upper body out of the water.

Phonotaxis trials were only conducted for males and females that underwent hibernation. All hibernated individuals (16 females and 8 males) underwent 2 trial periods: once before hibernation and again after the $60 \mathrm{~d}$ hibernation. The trials were carried out in an opaque rectangular plastic enclosure measuring $124 \mathrm{~cm} \mathrm{(l)} \times 64 \mathrm{~cm} \mathrm{(w)} \times 48 \mathrm{~cm}(\mathrm{~h})$. Laboratory tape was placed on the floor of the enclosure to provide a visual reference of frog position that subdivided the enclosure into 4 sections measuring $31 \mathrm{~cm} \mathrm{(l)} \times 64 \mathrm{~cm} \mathrm{(w)}$. Section 1 was closest to the active speaker and Section 4 was farthest. Water $\left(2.5 \mathrm{~cm}\right.$ deep and at a temperature of $19^{\circ} \mathrm{C}$ ) was added to the enclosure before each trial. The enclosure was rinsed and replaced with new water 
between trials. Advertisement calls were played back from a computer connected to a Saul Mineroff Electronics model SME-AFS amplified field speaker. The decibel (dB) levels during playback ranged between 60.7 and $54.5 \mathrm{~dB}$ in the middle of Section 1, 52.3 and $48.5 \mathrm{~dB}$ in the middle of the enclosure, and 48.9 and $45.8 \mathrm{~dB}$ in the middle of Section 4. Before the start of each trial, frogs were confined to an opaque acclimation container in the center of the enclosure for $2 \mathrm{~min}$. This allowed the frog to become accustomed to the water conditions (Bee 2007). During the acclimation period, the playback speaker was turned on. Following the acclimation period, the container was removed from above using a rope. Each trial lasted $10 \mathrm{~min}$, and frog behavior was recorded using a digital camcorder placed above the enclosure. All trials were conducted between 10:00 and 14:00 $\mathrm{h}$ in an enclosed room illuminated with a fluorescent ceiling light. All researchers left the room during behavioral recordings. Phonotaxis video recordings were analyzed to determine the percentage of time frogs spent in each section of the enclosure. All observers were blind to the frogs' hibernation treatment during analyses. Some frogs exhibited high stress behavior characterized by repeated vertical jumps along the enclosure wall (Bee 2007). Other frogs remained sedentary for extended periods during the trial. When frogs exhibited high stress or sedentary behavior for a continuous period of more than $2 \mathrm{~min}$, the data from these trials were excluded from analyses. Frogs exhibiting these behaviors were re-tried a second time $3 \mathrm{~d}$ after the first trial.

\section{Reproductive behaviors}

We compared the frequency of reproductive behaviors between hibernated and non-hibernated breeding pairs in 4 experimental treatment groups.
These groups ( $\mathrm{n}=8$ pairs per group) consisted of (1) hibernated males and females, (2) hibernated males and non-hibernated females, (3) non-hibernated males and hibernated females, and (4) nonhibernated males and females. Frogs were paired based on their BCI in order to limit size differences between pairs and thereby maximize the chances of a successful reproductive encounter. Because there were twice as many females in the captive population, each male was sequentially paired with 2 females. Every male was paired with both a hibernated and non-hibernated female in balanced order, so that half the males were first paired with hibernated females and the other half were first paired with non-hibernated females. Breeding pairs were housed in a 3781 tank subdivided into 4 sections with opaque plastic dividers. Each section had a footprint $61 \mathrm{~cm}$ long and $30 \mathrm{~cm}$ wide with a small land area composed of a rocky substrate. Water depth was $15 \mathrm{~cm}$, and a large rock was provided as an oviposition site. Water temperature was maintained at $13^{\circ} \mathrm{C}$ during the experiment. Artificial lighting was provided with a Phillips $40 \mathrm{~W}$ cool white bulb and a Sylvania $40 \mathrm{~W}$ black light bulb on a 07:00 to 17:00 h (10 h light: $14 \mathrm{~h}$ dark) photoperiod designed to mimic spring. An ethogram of 6 behaviors was used to measure the reproductive activity of breeding pairs (Table 1). Amplexus and male advertisements were used as metrics of male reproductive interest. Female reproductive interest was measured using release calls, disengagement from males, and escape behavior. Oviposition was used as a final metric to determine the reproductive response of frogs.

A continuous scan sampling design was used to record behaviors at $1 \mathrm{~min}$ intervals during $60 \mathrm{~min}$ observation periods for 3 sessions (morning, midday and afternoon) per day. Four pairs of frogs housed in the same tank were observed simultaneously per

Table 1. Ethogram of the 6 reproductive behaviors scored during observations for all 4 hibernation treatment groups (hibernated males and females; hibernated males, non hibernated females; non-hibernated males, hibernated females; nonhibernated males and females) of mountain yellow-legged frogs Rana muscosa

\begin{tabular}{|ll|}
\hline Behavior & Definition \\
\hline Amplexus & Male is on top of the female with his forelimbs pressed against her pectoral region \\
Advertisement call & Male emits a mate attraction call \\
Release call & While in amplexus, the female calls to signify a lack of receptivity \\
Disengagement & Female and male separate from amplexus \\
Escape behavior & While in amplexus, the female uses her forelimbs to rub on the male's forelimbs and/or kicks his \\
Oviposition & body with her hindlimbs \\
\hline
\end{tabular}


session. Trials occurred over 2 consecutive days for each unique pair, totaling 6 observation sessions. Any pairs in which females produced eggs were immediately removed from the trials in order to minimize disturbance to the clutch.

Breeding pairs were introduced $30 \mathrm{~min}$ prior to the first observation session, allowing them to acclimate to their new environment. Pairs were housed together overnight without separation for $48 \mathrm{~h}$ after their initial pairing (unless oviposition occurred). By maintaining continuous pairing during observations, we minimized handling and created a more natural breeding environment.

\section{Data analysis}

We used a repeated measures 2-factor ANOVA to compare changes in BCI over the $60 \mathrm{~d}$ hibernation period, with sex and hibernation status as the 2 factors. For phonotaxis, we separately compared the response of male and female frogs before and after hibernation to evaluate the hypothesis that hibernation would increase their phonotaxic response. An Anderson-Darling test indicated that the raw data did not meet assumptions of normality, so the data was log transformed prior to analysis. We used a paired $t$-test for each sex to compare time spent in Section 1 between the 2 trials.

Reproductive behaviors were summed over all observation periods to arrive at a cumulative frequency of each behavior for each pair. Male behavior data (amplexus and advertisement call) were still non-normal after transformation (Anderson-Darling test), so we used a non-parametric Kruskal-Wallis test to compare these behaviors between all 4 treatment groups, with Mann-Whitney $U$ planned comparison post hoc tests. Female rejection behaviors (release call, disengagement, escape) could only occur after their male partner initiated amplexus. As a result, female rejection behaviors occurred very infrequently in the treatments where females were paired with non-hibernated males because their partners rarely engaged them in amplexus. Thus, we only compared female rejection behaviors between the 2 treatments with hibernated males, using a Mann-Whitney $U$-test. We used a 2tailed Fisher's exact test to compare the frequency of oviposition across all treatment groups.

\section{RESULTS}

\section{Body condition}

The mean weight of hibernated frogs decreased by $2.2 \mathrm{~g}$ for females and $2.6 \mathrm{~g}$ for males. The mean weight of non-hibernated frogs increased by $1.3 \mathrm{~g}$ for females and decreased by $0.4 \mathrm{~g}$ for males (see Table 2 for summary data). Females had a significantly greater BCI than males at both Time 1 and Time 2 (2-factor ANOVA, $F_{1,46}=5.77, \mathrm{p}=0.02$ ). Hibernated frogs had a significantly lower BCI than non-hibernated frogs after hibernation $\left(F_{1,46}=43.30\right.$, $\mathrm{p}=0.0001$ ). We found no interaction effect between the frogs' sex and hibernation treatment on BCI $\left(F_{1,46}=1.46, \mathrm{p}=0.23\right)$.

\section{Phonotaxis}

Two males and 3 females were excluded from analyses because they exhibited high stress or sedentary behaviors during trials. The final sample size included 6 males and 13 females. Females that underwent hibernation did not exhibit a significant difference in the time spent in front of the active speaker (Section 1) before and after hibernation ( $\mathrm{df}=$ $15, t=-0.08, \mathrm{p}=0.93$ ). Females spent $23 \pm 4 \%$ (mean $\pm \mathrm{SE}$ ) of their time in Section 1 prior to hibernation and $26 \pm 2 \%$ following hibernation. Hibernated males spent significantly more time in front of the active speaker after hibernation $(\mathrm{df}=5, t=-3.89, \mathrm{p}=$ 0.01). The mean time that males spent in the section closest to the speaker increased from $20 \pm 10 \%$ prior to hibernation to $40 \pm 12 \%$ following hibernation. Of the 6 males used in final analysis, 4 increased the amount of time spent in Section 1 following hibernation (Table 3).

Table 2. Summary data for mean (with SE in parentheses) body condition index (BCI) and weight of hibernated and non-hibernated male and female mountain yellow-legged frogs Rana muscosa. Time 1, Time 2: before and after any frogs were hibernated, respectively

\begin{tabular}{|lccccc|}
\hline \multicolumn{2}{c}{ Females } & Males & \multicolumn{2}{c|}{ Non-hibernated } \\
& & & & \\
& & & & \\
Mean BCI & & & & \\
Time 1 & $0.589(0.038)$ & $0.447(0.026)$ & $0.558(0.025)$ & $0.452(0.030)$ \\
Time 2 & $0.551(0.033)$ & $0.401(0.028)$ & $0.578(0.025)$ & $0.446(0.032)$ \\
Mean weight (g) & & & & \\
Time 1 & $35.9(2.4)$ & $26.0(1.8)$ & $35.9(2.2)$ & $26.4(2.0)$ \\
Time 2 & $33.7(2.2)$ & $23.4(1.9)$ & $37.2(2.1)$ & $26.0(2.1)$ \\
\hline
\end{tabular}


Table 3. Percent of time spent by 6 male mountain yellowlegged frogs Rana muscosa in Section 1 (closest to the speaker) of the experimental enclosure before and after hibernation

\begin{tabular}{|ccc|}
\hline \multirow{2}{*}{ ID } & \multicolumn{2}{c|}{ Time in Section 1 (\%) } \\
& Pre-hibernation & Post-hibernation \\
\hline 1 & 17 & 0 \\
2 & 21 & 80 \\
3 & 7 & 54 \\
4 & 3 & 24 \\
5 & 9 & 30 \\
6 & 66 & 55 \\
\hline
\end{tabular}

\section{Reproductive behaviors}

There was a significant difference between groups in the rate of male advertisement calls (KruskalWallis test, $\mathrm{df}=2, h=8.97, \mathrm{p}=0.01$ ), with hibernated males calling more frequently than non-hibernated males (Mann-Whitney $U$ planned-comparison test, $\mathrm{df}=1, U=77, \mathrm{p}=0.05)$. There was also a significant difference in male amplexus rates among treatment groups (Kruskal-Wallis test, df $=3, h=23.13, \mathrm{p}<$ 0.01). Hibernated males exhibited a significantly higher rate of amplexus than non-hibernated males (Mann-Whitney $U$ planned-comparison test, df $=1$, $U=260, \mathrm{p}<0.01)$. Eleven hibernated males were in amplexus nearly continually (i.e. in $>95 \%$ of observations), whereas this was only the case for 1 nonhibernated male.

Regarding female behaviors, individuals who were not hibernated produced significantly more release calls (Mann-Whitney $U$-test, $\mathrm{df}=1, U=12, \mathrm{p}=0.04$ ), but hibernation treatment did not have a significant influence on female disengagement (Mann-Whitney $U$-test, $\mathrm{df}=1, U=41, \mathrm{p}=0.24$ ) or escape behaviors (Mann-Whitney $U$-test, df $=1, U=33, \mathrm{p}=0.92$; Table 4). We found a significant difference in oviposition between hibernated and non-hibernated females (Fisher's exact test, $\mathrm{p}=0.02$; Table 4 ). Of the 16 non-hibernated females, none oviposited, while 6 of the 16 hibernated females oviposited. Four of the females who laid eggs were in amplexus with hibernated males, resulting in fertilized clutches. The remaining 2 females were paired with non-hibernated males and laid eggs without their male partners initiating amplexus, resulting in unfertilized clutches.

\section{DISCUSSION}

\section{Body condition}

The reduced body condition observed in hibernated frogs was not surprising since stored energy reserves are drawn upon to maintain basic metabolic functions during hibernation. In terms of weight loss, hibernated females lost a mean of $6.1 \%$ of their body weight and hibernated males lost 10.2\%. These weight reductions are important and could have real effects on animal welfare. However, substantial weight loss in wild Rana muscosa is likely, given that hibernation exceeds the $60 \mathrm{~d}$ period used in our trials (Holenweg \& Reyer 2000). Our concern over possible excessive erosion of body condition in our captive colony led us to choose a conservative hibernation duration, yet we were still able to significantly increase reproductive behaviors and output.

\section{Phonotaxis}

Our results indicate that male $R$. muscosa have an increased attraction to advertisement calls following hibernation, but that females do not. While this finding is unexpected, fundamental differences in breeding biology between males and females may drive these different responses. Male anurans sometimes display increased territoriality and aggression during the breeding season in the form of increased site tenacity and physical attacks (Ovaska 1987, Shepard 2004). While $R$. muscosa is not known to have an aggressive call in its repertoire, we have observed captive males in amplexus with other males for extended periods. This may be a form of male-male competition, and suggests that phonotaxis of male $R$. muscosa to conspecific advertisement calls may be

Table 4. Mean (with SE in parentheses) frequency of reproductive behaviors for hibernated and non-hibernated mountain yellow-legged frogs Rana muscosa. Statistically significant differences $(\mathrm{p} \leq 0.05)$ between hibernated and non-hibernated frogs are highlighted in bold. See Table 1 for descriptions of the behaviors

\begin{tabular}{|lcccc|}
\hline Behavior & \multicolumn{2}{c}{ Cumulative frequency } & \multicolumn{2}{c|}{$\begin{array}{c}\text { Mann Whitney } U \text {-test } \\
\text { between groups } \\
\text { p }\end{array}$} \\
& Hibernated & Non-hibernated & Sample size \\
\hline Amplexus & $0.88(0.05)$ & $0.02(0.01)$ & $<\mathbf{0 . 0 1}$ & 32 \\
Advertisement call & $0.37(0.15)$ & $0.02(0.01)$ & $\mathbf{0 . 0 5}$ & 32 \\
Release call & $0.08(0.05)$ & $0.24(0.08)$ & $\mathbf{0 . 0 4}$ & 16 \\
Disengagement & $0.19(0.11)$ & $0.13(0.06)$ & 0.24 & 16 \\
Escape behavior & $0.25(0.10)$ & $0.16(0.05)$ & 0.92 & 16 \\
\hline
\end{tabular}


related to a territorial or aggressive response. Alternatively, $R$. muscosa may use conspecific male calls as beacons to improve the probability of finding receptive females by locating areas of breeding activity.

The use of a single male frog call recording for playbacks may have influenced the lack of phonotaxis by female frogs, especially if selective females deemed the call to be of low quality from a sexual selection perspective. We acknowledge that the small sample size of male frogs in the phonotaxis experiment limits our ability to make definitive conclusions, but our results at least suggest that male phonotaxis may be primed by hibernation. Further research is needed to confirm the results of male phonotaxic behavior and to determine whether female phonotaxic behavior can also be encouraged in different hibernation regimes or experimental contexts (e.g. Narins et al. 2005).

\section{Reproductive behavior}

R. muscosa appears to require a hibernation period for successful reproduction. The effects of hibernation were manifested in vocal advertisement signaling, amplexus, female receptivity, and oviposition. Each of these behaviors plays an important role, leading to successful reproduction in $R$. muscosa, and by taking a behavioral approach, we were able to observe how hibernation catalyzed this repertoire of interacting behaviors that are critical for successful reproduction.

The male advertisement call establishes communication between males and females and is fundamental for reproduction in anurans (Duellman \& Trueb 1994). The increased frequency of calling observed in hibernated male $R$. muscosa no doubt served to help establish amplexus, which stimulates female egg release and fertilization (see also Passmore et al. 1992, Dyson et al. 1998, Prohl 2003, Bosch \& Marquez 2005, Richardson et al. 2010). Virtually all (88\% of observations) hibernated males established amplexus with females, while almost none ( $2 \%$ of observations) of the non-hibernated males did so. Females can influence the outcome of amplexus by signaling a lack of receptivity, and non-hibernated females were more likely to emit release calls during amplexus compared to hibernated females. Maintaining amplexus is costly for females because they cannot eat, have restricted mobility (Bowcock et al. 2009), and can drown if they are in amplexus simultaneously with multiple competing males (Sztatecsny et al. 2006).
Moreover, only hibernated females laid eggs and only hibernated males successfully fertilized eggs. Two females laid eggs despite the fact that they were never observed to be in amplexus with males. This is a testament to the influence of hibernation on female reproductive ability. Such a dependency on hibernation is not surprising, since it is a major component of the natural conditions that $R$. muscosa experiences in the wild.

\section{CONCLUSIONS}

Although the use of hibernation in amphibian propagation is not new, systematic investigation of hibernation effects is rare, which may be a reason why this method has not been widely adopted. We demonstrated that simple husbandry changes to mimic natural hibernation conditions can dramatically improve reproductive success of Rana muscosa in captivity. Future research should address other hibernation regimes in the hope of stimulating greater reproductive rates.

Perhaps more than for any other taxa, conservation breeding programs will be a primary tool for amphibian species rescue and recovery (Gascon et al. 2007, Gratwicke et al. 2012). At present, many anuran conservation breeding programs depend on hormone treatments (Browne et al. 2006, Byrne \& Silla 2010, Kouba et al. 2012). While hormone treatments can improve reproductive output, the proper cocktail and dose required varies widely across species (Kouba et al. 2009). The frequent handling and experimentation required to establish a hormone regiment can also lead to high levels of stress (Narayan et al. 2011) or reduce general activity and feeding behaviors (Bliley \& Woodley 2012). Therefore, hormone treatments should be used cautiously, especially in breeding programs that rely on a small number of reproductive individuals. We recommend that amphibian conservation breeding programs initially focus on non-invasive husbandry practices that mimic natural conditions and utilize information about the behavioral and ecological requirements of the species.

Additional research should also be pursued on a wider array of temperate amphibian taxa to establish the generality of these approaches. The manipulation of seasonal cycles in the captive setting can also be applied to tropical and temperate anuran species that increase reproductive activity with shifts in other environmental cues such as humidity, temperature, and rainfall patterns (Hsu et al. 2006, Richter-Boix et al. 2006, Van Sluys et al. 2006, Lucas et al. 2008). 
By recreating key environmental cues, amphibian breeding programs may be able to improve captive conditions and increase reproductive outputs.

Acknowledgements. We thank Adam Backlin and Elizabeth Gallegos for their insight and advice in the development of this research, as well as Shannon Hoss, Matthew Barbour, and Tina Tran from the Clark Lab at San Diego State University for their support with data analyses and interpretation. Dr. Matt Anderson and Jennifer Keating provided assistance with the auditory aspects of this research. Peter Gilson, Colleen Wisinski, and Alan Lieberman assisted with behavioral observations. We also thank the 3 anonymous reviewers of this manuscript who provided valuable constructive criticism and feedback. This research was funded by grants from the United States Forest Service agreement number 09-CS-11051200-024 and amendments, the Conservation Endowment Fund of the Association of Zoos and Aquariums, and by San Diego Zoo Global. All research was conducted under the Institutional Animal Care and Use Committee no. 10-002 at the San Diego Zoo Institute for Conservation Research, USFWS recovery permit no. TE-045994, and DFG Scientific Collecting Permit no. 11398. This is contribution 466 of the USGS Amphibian Research and Monitoring Initiative. The use of trade, product, or firm names in this publication does not imply endorsement by the US Government.

\section{LITERATURE CITED}

Arch VS, Narins PM (2009) Sexual hearing: the influence of sex hormones on acoustic communication in frogs. Hear Res 252:15-20

Bee MA (2007) Selective phonotaxis by male wood frogs (Rana sylvatica) to the sound of a chorus. Behav Ecol Sociobiol 61:955-966

Bliley JM, Woodley SK (2012) The effects of repeated handling and corticosterone treatment on behavior in an amphibian (Ocoee salamander: Desmognathus ocoee). Physiol Behav 105:1132-1139

Bosch J, Marquez R (2005) Female preference intensities on different call characteristics and symmetry of preference above and below the mean in the Iberian midwife toad Alytes cisternasii. Ethology 111:323-333

Bosch J, Marquez R, Boyero L (2003) Behavioural patterns, preference, and motivation of female midwife toads during phonotaxis tests. J Ethol 21:61-66

Bowcock H, Brown GP, Shine R (2009) Beastly bondage: the costs of amplexus in cane toads (Bufo marinus). Copeia 2009:29-36

Bradford DF (1983) Winterkill, oxygen relations, and energy metabolism of a submerged dormant amphibian, Rana muscosa. Ecology 64:1171-1183

Bradford DF (1984) Temperature modulation in a highelevation amphibian Rana muscosa. Copeia 1984: 966-976

Browne RK, Zippel K (2007) Reproduction and larval rearing of amphibians. ILAR J 48:214-234

Browne RK, Seratt J, Vance C, Kouba A (2006) Hormonal priming, induction of ovulation and in-vitro fertilization of the endangered Wyoming toad (Bufo baxteri). Reprod Biol Endocrinol 4:34, doi:10.1186/1477-7827-4-34

Byrne PG, Silla AJ (2010) Hormonal induction of gamete release, and in-vitro fertilisation, in the critically endan- gered Southern Corroboree Frog, Pseudophryne corroboree. Reprod Biol Endocrinol 8:144, doi:10.1186/14777827-8-144

Duellman WE, Trueb L (1994) Biology of amphibians. Johns Hopkins University Press, Baltimore, MD

Dyson ML, Bush SL, Halliday TR (1998) Phonotaxis by female Majorcan midwife toads, Alytes muletensis. Behaviour 135:213-230

Gascon C, Collins JP, Moore RD, Church DR, McKay JE, Mendelson JR III (eds) (2007) Amphibian conservation action plan. IUCN/SSC Amphibian Specialist Group, Gland

Goense JBM, Feng AS (2005) Seasonal changes in frequency tuning and temporal processing in single neurons in the frog auditory midbrain. J Neurobiol 65:22-36

Gratwicke B, Lovejoy TE, Wildt DE (2012) Will amphibians croak under the Endangered Species Act? Bioscience 62: 197-202

Griffiths RA, Pavajeau L (2008) Captive breeding, reintroduction, and the conservation of amphibians. Conserv Biol 22:852-861

> Hoffmann M, Hilton-Taylor C, Angulo A, Bohm M and others (2010) The impact of conservation on the status of the world's vertebrates. Science 330:1503-1509

> Holenweg AK, Reyer HU (2000) Hibernation behavior of Rana lessonae and $R$. esculenta in their natural habitat. Oecologia 123:41-47

Hosey GR, Melfi V, Pankhurst S (2009) Zoo animals: behaviour, management, and welfare. Oxford University Press, New York, NY

Hsu MY, Kam YC, Fellers GM (2006) Temporal organization of an anuran acoustic community in a Taiwanese subtropical forest. J Zool 269:331-339

Karraker NE, Welsh HH (2006) Long-term impacts of evenaged timber management on abundance and body condition of terrestrial amphibians in Northwestern California. Biol Conserv 131:132-140

Kim JW, Im WB, Choi HH, Ishii S, Kwon HB (1998) Seasonal fluctuations in pituitary gland and plasma levels of gonadotropic hormones in Rana. Gen Comp Endocrinol 109:13-23

Kouba AJ, Vance CK, Willis EL (2009) Artificial fertilization for amphibian conservation: current knowledge and future considerations. Theriogenology 71:214-227

> Kouba A, Willis E, Vance C, Hasenstab S and others (2012) Development of assisted reproduction technologies for the endangered Mississippi gopher frog (Rana sevosa) and sperm transfer for in vitro fertilization. Reprod Fertil Dev 24:170

> Lima NGD, Gontijo ASB, Eterovick PC (2014) Breeding behaviour of Bokermannohyla nanuzae (Anura: Hylidae) at an Atlantic Forest site in southeastern Brazil. J Nat Hist 48:1439-1452

Lucas EM, Brasileiro CA, Oyamaguchi HM, Martins M (2008) The reproductive ecology of Leptodactylus fuscus (Anura, Leptodactylidae): new data from natural temporary ponds in the Brazilian Cerrado and a review throughout its distribution. J Nat Hist 42:2305-2320

Lynch KS, Wilczynski W (2005) Gonadal steroids vary with reproductive stage in a tropically breeding female anuran. Gen Comp Endocrinol 143:51-56

Lynch KS, Crews D, Ryan MJ, Wilczynski W (2006) Hormonal state influences aspects of female mate choice in the Túngara frog (Physalaemus pustulosus). Horm Behav 49:450-457 
Miranda JA, Wilczynski W (2009) Female reproductive state influences the auditory midbrain response. J Comp Physiol A Sens Neural Behav Physiol 195:341-349

Narayan EJ, Molinia FC, Cockrem JF, Hero JM (2011) Changes in urinary testosterone and corticosterone metabolites during short-term confinement with repeated handling in wild male cane toads (Rhinella marina). Aust J Zool 59:264-269

Narins PM, Grabul DS, Soma KK, Gaucher P, Hodl W (2005) Cross-modal integration in a dart-poison frog. Proc Natl Acad Sci USA 102:2425-2429

Ovaska K (1987) Seasonal-changes in agonistic behavior of the western red-backed salamander, Plethodon vehiculum. Anim Behav 35:67-74

Passmore NI, Bishop PJ, Caithness N (1992) Calling behavior influences mating success in male painted reed frogs, Hyperolius marmoratus. Ethology 92:227-241

Preininger D, Boeckle M, Sztatecsny M, Hodl W (2013) Divergent receiver responses to components of multimodal signals in two foot-flagging frog species. PLoS ONE 8:e55367

Prohl H (2003) Variation in male calling behaviour and relation to male mating success in the strawberry poison frog (Dendrobates pumilio). Ethology 109:273-290

Reading CJ (2007) Linking global warming to amphibian declines through its effects on female body condition and survivorship. Oecologia 151:125-131

Reichert MS (2013) Visual cues elicit courtship signals in a nocturnal anuran. Behav Ecol Sociobiol 67:265-271

> Richardson C, Joly P, Lena JP, Plenet S, Lengagne T (2010) The challenge of finding a high-quality male: a treefrog solution based on female assessment of male calls. Behaviour 147:1737-1752

Richter-Boix A, Llorente GA, Montori A (2006) Breeding phenology of an amphibian community in a Mediterranean area. Amphib-Reptilia 27:549-559

Roth TL, Szymanski DC, Keyster ED (2010) Effects of age, weight, hormones, and hibernation on breeding success in boreal toads (Bufo boreas boreas). Theriogenology 73: 501-511

Schoville SD, Tustall TS, Vredenburg VT, Backlin AR, Gallegos E, Wood DA, Fisher RN (2011) Conservation genet-

Editorial responsibility: Nicholas Tolimieri, Seattle, Washington, USA ics of evolutionary lineages of the endangered mountain yellow-legged frog, Rana muscosa (Amphibia: Ranidae), in southern California. Biol Conserv 144:2031-2040

Schwartz JJ, Huth K, Hutchin T (2004) How long do females really listen? Assessment time for female mate choice in the grey treefrog, Hyla versicolor. Anim Behav 68: 533-540

> Shepard DB (2004) Seasonal differences in aggression and site tenacity in male green frogs, Rana clamitans. Copeia 2004:159-164

Swaisgood RR (2007) Current status and future directions of applied behavioral research for animal welfare and conservation. Appl Anim Behav Sci 102:139-162

Swaisgood RR (2010) The conservation-welfare nexus in reintroduction programmes: a role for sensory ecology. Anim Welf 19:125-137

> Sztatecsny M, Jehle R, Burke T, Hoedl W (2006) Female polyandry under male harassment: the case of the common toad (Bufo bufo). J Zool 270:517-522

Van Sluys M, Rico M, Rocha CFD (2006) Seasonal and hourly patterns of reproductive activity in Scinax trapicheiroi (Anura, Hylidae), Rio de Janeiro State, southeastern Brazil. Herpetol J 16:15-20

Vredenburg VT, Bingham R, Knapp R, Morgan JAT, Moritz C, Wake D (2007) Concordant molecular and phenotypic data delineate new taxonomy and conservation priorities for the endangered mountain yellow-legged frog. J Zool 271:361-374

Waggener WL, Carroll EJ (1998) A method for hormonal induction of sperm release in anurans (eight species) and in vitro fertilization in Lepidobatrachus species. Dev Growth Differ 40:19-25

Wall P (2010) Conservation and animal welfare: consensus statement and guiding principles. Anim Welf 19:191-192

> Wells KD (1977) Social behaviour of anuran amphibians. Anim Behav 25:666-693

Wilczynski W, Lynch KS (2011) Female sexual arousal in amphibians. Horm Behav 59:630-636

Zippel K, Johnson K, Gagliardo R, Gibson R and others (2011) The Amphibian Ark: a global community for ex situ conservation of amphibians. Herpetol Conserv Biol $6: 340-352$

Submitted: May 21, 2013; Accepted: September 18, 2014 Proofs received from author(s): January 10, 2015 